\title{
A STRATEGY FOR THE TREATMENT OF PATIENTS WITH CORONARY ARTERY DISEASE AND THE PRESENCE OF SIGNIFICANT CAROTID ARTERY STENOSIS: ANALYSIS OF THE "STAGED" AND "CONCOMITANT" APPROACHES
}

\author{
Saša S. Živići ${ }^{1}$ Dragan J. Milić1, ${ }^{2}$, Mile Vraneš3 ${ }^{3}$ Miloš Velinović3 \\ Dragan C. Bogdanović 4
}

\begin{abstract}
Today, there is no unequivocal overview of how to treat patients undergoing myocardial revascularization and have associated significant carotid artery stenosis. In this group of patients, there are several ways to treat, and our study analyzed patients who were exposed to a "Staged" and "Concomitant" approach.

During 2016 in three cardiac surgery centers of Serbia, the perioperative results of the patients subjected to a "Staged" and "Concomitant" approach were analyzed. Group 1 including patients with cardiac revascularization and endarterectomy was made at least 30 days earlier, and group 2 consisted of patients who underwent endarterectomy with cardiac revascularization simultaneously. In both groups, CVI appearance was observed 7 days after the revascularization of the heart. We followed the risk factors for the occurrence of CVI.

The conducted study included a total of 49 patients, divided into two groups. In 28 patients (group 1) Eversion Carotid endarterectomy was performed 30 days to 26 months prior to coronary revascularization. The average age of patients was 64 and 65 years, with the prevalence of male sex ( $86 \%: 14 \%)$. The only parameters that showed a significant difference between the groups were "left main syndrome" and unstable angina pectoris, both in Group 2. In the ensuing period, in both groups, there were no postoperative major neurological events (CVI). In one patient, clinical signs of neurological deficits occurred in the form of weakness of one side of the body, but CVI was not proven by CTom and MRA. effective.

It can be concluded that the "Staged" and "Concomitant" approaches are safe and
\end{abstract}

Acta Medica Medianae 2019;58(1):44-49.

Key words: myocardial revascularization, carotid artery stenosis, Staged approach, Concomitant approach

\footnotetext{
${ }^{1}$ Clinical center Niš, Cardiovascular and transplant surgery Clinic, Niš, Serbia

${ }^{2}$ University of Niš, Faculty of Medicine, Niš, Serbia

${ }^{3}$ Clinical center Serbia, Cardiovascular diseases clinic, Belgrade, Serbia

${ }^{4}$ Public health Institute Niš, Niš, Serbia
}

Contact: Saša Živić

Blvd. Dr Zoran Djindjić 48, 18000 Niš, Serbia

E-mail: zivicdr@gmail.com

\section{Introduction}

Cardiovascular disease is the leading cause of morbidity and mortality in the world, responsible for 17.3 million deaths a year and is expected to rise to 23.6 million by $2030 . y$. About $80 \%$ of these deaths occur in low and medium-developed countries (1), which includes our country. Ischemic heart disease, caused predominantly by arteriosclerosis, is the most common form of heart disease. Arteriosclerosis is a diffuse process involving various vascular systems with significant overlap between coronary, cerebrovascular and peripheral arterial systems (2).

This condition is associated with similar predisposing risk factors and genetic predisposition. In the population of patients with coronary artery disease, the presence of $11.1-25.4 \%$ of cerebrovascular disease was observed $(3,4)$. One of the main risk factors for the development of arteriosclerotic disease, which equally affects the development of CAD and $C V D$, is age. All clinical studies show an increasing average age of patients undergoing $C A B G$, so the risk of a significant CVD is increasing. The average age of 56 years old in 1980 jumped to 68 in 2001.y. In 1980 , only $6 \%$ of patients were older than 70 years old, while according to data from 2001, even $45 \%$ were older than 70 and $13 \%$ older than 80 
years (5). Stroke is a devastating complication that occurs in myocardial revascularization, not only because of the devastating consequences for the patient but also because of the increased costs of hospitalization and post-hospital care.

The rate of mortality among those who have experienced CVI is very high, close to $25 \%$, with an average stay in hospital 28 days $(6,7)$. The risk of stroke in patients undergoing CABG is well defined. In 1986, Gardner et al. (8) found that the risk of stroke was in direct proportion to the age of the patient. Patients under 45 years of age have a statistically defined risk of $0.2 \%$, and it rises to $3 \%$ for patients in sixties and $8 \%$ for patients over 79 years of age. Other risk factors associated with stroke in the perioperative period are previous neurological events (CVI, TIA), arteriosclerosis of the ascendant aorta, duration of cardiopulmonary bypass, and perioperative hypotension. The effectiveness of surgical treatment of significant carotid artery stenosis at the distant stroke is clear in all studies and has the highest possible level of recommendation today (9-15).

In many clinical studies, it has been shown that more than $50 \%$ of patients who come because of a significant carotid artery stenosis have coronary artery disease. Even $25 \%$ of them have a significant coronary disease, $7 \%$ have a severe inoperable coronary disease, and only about $7 \%$ have normal coronary blood vessels $(16,17)$.

The only question that becomes apparent when there is coronary artery disease with an indication for operative care and significant carotid stenosis is the choice of approach to the management of both diseases.

One approach is the performance of carotid endarterectomy and CABG as a stepwise procedure, carotid endarterectomy, and CABG ("staged" procedure), with endarterectomy being performed prior to the establishment of extracorporeal circulation (1821). Most surgeons recommend this type of operative approach, especially for patients who have stable angina pectoris and who are hemodynamically stable (5). The introduction of everzione method and regional anesthesia (block) significantly improved the results in relation to the perioperative occurrence of stroke, death, and myocardial infarction.

The second approach is simultaneous, synchronous approach ("Concomitant"). Bernhard was the first one to report it in 1972. in 15 patients, in whom he performed endarterectomy of significant carotid artery stenosis and coronary revascularization in general anesthesia (5).

Daily in his analysis, he said that this approach does not lose efficiency and saves in the course of treatment (22).

\section{Material and methods}

The patients were treated with CABG in the Clinical Center of Serbia Clinic for cardiac surgery, KBC Dedinje and KC Niš Clinic for cardiovascular with transplant surgery, in the period from $1^{\text {st }}$ January to $31^{\text {st }}$ December 2016, with significant carotid artery stenosis. The significance of carotid artery stenosis is defined with $\geq 70 \%$ with the help of color duplex scans. Patients were divided into two groups:

Group 1. - Everzione endarterectomy of the carotid artery was performed at least 30 days prior to coronary revascularization

Group 2 - everzional endarterectomy of the carotid artery was performed synchronously with myocardial revascularization.

After myocardial revascularisation, CVI was confirmed by CT or MR in 7 days.

We analyzed the parameters that were emphasized in the literature as predictors of intra and perioperative CVI - perfusion pressure on EKK, length of occlusal clamp, duration of EKK, body temperature during EKK, representation of LM, perioperative arterial pressure.

The exclusion parameters were endovascular treatment of significant carotid artery stenosis, the presence of significant carotid artery stenosis on both sides, and the presence of atheromatous plaques on the ascending aorta.

\section{Results}

The conducted study included a total of 49 patients in 3 cardiovascular institutions (Clinic for Cardiac Surgery of the Clinical Center C of Serbia, IKVB Dedinje, Clinic for Cardiovascular with Transplantation Surgery KC Niš), divided into two groups.

In 28 patients (Group 1), endarterectomy of the carotid artery was performed for 30 days to 26 months, and on average $9.61 \pm 6.97$ months before coronary revascularization. In 21 patients (Group 2), endarterectomy of the carotid artery was performed synchronously with myocardial revascularization. In Group 1 age ranged from 54 to 73 years, and on average it was $63.86 \pm 4.84$ years. In Group 2, the average age was somewhat higher and amounted to $65.19 \pm 3.98$ years, and ranged from 58 to 72 years without significant difference compared to Group 1 $(p=0.310)$.

In Group 1 there were 25 (89.3\%) men and 3 (10.7\%) women. In Group 2 (80.9\%) there were 17 men and 4 (19.0\%) women.

There was no significant difference in the presence of significant localized carotid artery stenosis in relation to the side in both groups.

In the group of patients in whom the endarterectomy was performed prior to the CABG, the perfusion pressure value ranged from 55 to $70 \mathrm{mmHg}$, and on average it was $63.75 \pm 2.93 \mathrm{mmHg}$.

In the group of patients in whom the endarterectomy was performed synchronously with CABG, the average perfusion pressure was slightly higher and amounted to $64.05 \pm 2.56 \mathrm{mmHg}$. It ranged from 60 to $70 \mathrm{mmHg}$. There was no significant difference between the perfusion pressure value in the two groups of patients compared ( $p=0.712)$.

In Group 1, the duration of the occlusion clamp ranged from 30 to 103 minutes, and on average it was $43.43 \pm 13.42$ minutes. In Group 2, the average duration of the occlusion clamp was somewhat shorter and amounted to $38.83 \pm 12.12$ minutes 
and ranged from 24 to 64 minutes, without significant difference between groups $(p=0.246)$.

In the group of patients in whom endarterectomy was performed prior to $C A B G$, the duration of EKK ranged from 55 to 158 minutes, and on average it was $79.57 \pm 9.08$ minutes. In the group of patients in whom the endarterectomy was performed synchronously with CABG, the average duration of EKK was slightly longer and amounted to $80.56 \pm 19.97$ minutes and ranged from 50 to 114 minutes. In the group of patients in whom the endarterectomy was performed prior to CABG the temperature was on average $33.04 \pm 1.07{ }^{\circ} \mathrm{C}$, and in the group of patients in whom the endarterectomy was performed synchronously with CABG the average temperature was somewhat higher and amounted to $33.71 \pm 2.00^{\circ} \mathrm{C}$.
In the group of patients in whom the endarterectomy was performed before the revascularization of myocardial HTA was observed in 18 (64.3\%) cases, and in the group of patients in whom the endarterectomy was performed synchronously with revascularization of myocardium HTA was recorded in a significantly higher percentage of HTA in two compared groups $p=0.014$ ).

In the group of patients in whom endarterectomy was performed prior to myocardial revascularization, LM stenosis was observed in 2 (7.1\%) cases, and in the group where the endarterectomy was performed synchronously with myocardial revascularization, LM was recorded in a significantly higher percentage, in $8(38,1 \%)$ of cases $(p=0.012)$. (Table 1.)

Table 1. The presence of stenosis of the left main coronary artery

\begin{tabular}{||c|c|c|c|}
\hline \multirow{2}{*}{ LM* } & \multicolumn{2}{|c|}{ Group } & \multirow{2}{*}{$\begin{array}{c}\text { In total } \\
(\mathrm{n}=49)\end{array}$} \\
\cline { 2 - 3 } & $\begin{array}{c}1 \\
(\mathrm{n}=28)\end{array}$ & $\begin{array}{c}2 \\
(\mathrm{n}=21)\end{array}$ & $39(79.6 \%)$ \\
\hline \hline No & $26(92.9 \%)$ & $13(61.9 \%)$ & $10(20.4 \%)$ \\
\hline Yes & $2(7.1 \%)$ & $8(38.1 \%)$ & $10(2)$ \\
\hline
\end{tabular}

*Left main

Unstable angina pectoris was recorded in 8 (38.1\%) patients in whom endarterectomy was performed synchronously with myocardial revascularization.

In a group of patients in whom endarterectomy was performed synchronously with myocardial revascularisation, there was one death outcome (4.8\%).

Postoperative agitation was reported in one patient $(4.8 \%)$ from the group of those in whom endarterectomy was performed synchronously with myocardial revascularization. Other postoperative complications have not been recorded. The patient who died during the operation had significant comorbidities left ventricular aneurysm and HOB. The cause of death was the inability to separate from cardiopulmonary by pass. The presence of HBI was recorded in one patient in the group of those in whom endarterectomy was performed synchronously with myocardial revascularization. Significant comorbidities were not observed in the group of patients in whom endarterectomy was performed prior to myocardial revascularisation. In the presence of comorbidity there were no significant differences between the groups compared ( $p=0.179)$.

Multivariate logistic regression analysis was the only significant factor that separated subjects from the two comparing groups confirming the presence of LM stenosis ( $p=0.016)$.

\section{Discussion}

Our study included a total of 49 patients divided into two groups. Group 1 (28 patients) who performed endarterectomy of the carotid artery at least a month before coronary surgery and Group 2 (21 patients) who had carotid endarterectomy were synchronized with coronary surgery.

In our study, the average age of patients was 64 and 65 years with the youngest patient aged 54 years and the oldest patient for 73 years. There was no significant difference in the age of patients in both groups.

The prevalence of male sex in our results is in line with world statistics (86\%: 14\%).

In the literature and in our results, no prevalence of involvement of some of the sides of the carotid artery stenosis was found.

The average value of the stenosis lesion in our study was $86 \%$, linking to the average age and according to the literature data indicates a severe degree of stenosis and a high potential for neurological events.

The average perfusion pressure value during cardiopulmonary bypass was approximately 64 $\mathrm{mmHg}$, not significantly higher in Group 2, and ranged between 55 and $70 \mathrm{mmHg}$. References cited as one of the main factors for the emergence of an intraoperative or perioperative stroke are just low perfusion pressure during cardiopulmonary bypass. Our data suggest that although patients were with 
high-grade stenoses of the carotid arteries ( $86 \%$ on average), even with contralateral stenosis at the significance limit or occlusion of the contralateral carotid artery, this pressure represents the safety for performing surgery regardless of the approach.

The average occlusion of the aorta lasted for 42 minutes (30-103 minutes) and there was no significant difference in the duration of aortic occlusion in two groups.

Aorta also represents one of the main sources of embolism, but in our results, there were no significant neurological events, which may indicate careful handling of an ascendant aorta.

The average length of cardiopulmonary bypass was 80 minutes without significant differences in the average duration per group.

One of the parameters that contributed to such good operative results was moderate hypothermia in patients because the average temperature at EKK was $33^{\circ} \mathrm{C}$. There was no significant difference in the groups.

There was no significant difference in the presence of risk factors for the development of arteriosclerotic disease in both groups. However, as the literature suggests, diabetes mellitus, hypertension, and hyperlipidemia have been seen as a risk factor for our patients as there was a significant presence in both groups.

Parameters that showed a significant difference between the groups were significant stenosis of the left coronary artery and unstable angina pectoris. However this discrepancy was a consequence of a different approach in patient care. Namely, surgeons more often opted for synchronous surgery in patients with unstable angina and high-risk patients due to the presence of stenosis of the left coronary artery, which is the recommendation of most surgeons in the world. In the literature, it is emphasized that in these patients the risk of myocardial infarction or CVI is increased in the "staged" procedure or "reverse staged" procedure, and the majority of authors recommend synchronous surgery.
There were no postoperative major neurological events (CVI) in the follow-up period, with one patient reporting clinical signs of neurological deficits in the form of weakness on one side of the body, but CT and MRA were not confirmed CVI.

One operation in group 2 was fatal due to haemodynamic instability and inability to separate from cardiopulmonary bypass, and the patient was with significant comorbidities (chronic obstructive pulmonary disease and left ventricular aneurysm with low ejection fraction).

\section{Conclusion}

Based on the conducted study, it can be concluded that the "Staged" procedure in the treatment of a group of patients with significant carotid artery stenosis and ischemic coronary disease represents a safe and effective procedure for patients who do not have unstable angina pectoris and who do not have a significant stenosis of the main tree of the left coronary artery.

The synchronous procedure is a safe and effective method for the group of patients who have a significant stenosis of the main tree of the left coronary artery with unstable angina pectoris with the presence of a significant carotid artery stenosis.

Perfusion pressure greater than $60 \mathrm{mmHg}$ during cardiopulmonary bypass, during coronary surgery in patients in a "Synchronous" or "Staged" procedure, represents the prevention of neurological events.

Moderate hypothermia during cardiopulmonary bypass, in the case of coronary surgery in patients in a "Synchronous" or "Staged" procedure, prevents neurological events.

One of the conclusions that arise is the requirement to examine the carotid artery system and in neurologically asymptomatic patients who are preparing for coronary revascularization. 


\section{References}

1. Mendis S, Puska P, Norrving B, editors. Global Atlas on Cardiovascular Disease Prevention and Control. Geneva: World Health Organization; 2011.

2. Criqui MH. Peripheral arterial disease - epidemiological aspects. Vascular Medicine 2001; 6 Suppl 1:3-7. [CrossRef] [PubMed]

3. Cheng SW, Wu LL, Lau $H$, Ting A, Wong J. Prevalence of significant carotid stenosis in Chinese patients with periferal and coronary artery disease. Aust NZJ Surg 1999; 69:44-7. [CrossRef] [PubMed]

4. Tanimoto S, Ikari Y, Tanabe K, Yachi S, Nakajima H, Nakayama $T$, et al. Prevalince of carotid artery stenosis in patients with coronary artery diseas in Japanese population. Stroke 2005; 36:2094-8.

[CrossRef] [PubMed]

5. Cohn HL. Cardiac surgery in the adult. 3th ed. Boston (MA): The McGraw-Hill Companies; 2008.

6. Shroyer $A L$, Coombs $L P$, Peterson ED, Eiken $M C$, DeLong ER, Chen A, et al. The Society of Thoracic Surgeons: 30-day operative mortality and morbidity risk models. Ann Thorac Surg 2003; 75:1856-64. [CrossRef] [PubMed]

7. Hogue WC Jr, Murphy SF, Schechtman KB, DávilaRomán VG. Risk factors for early or delayed stroke after cardiac surgery. Circulation 1999; 100:642-7. [CrossRef] [PubMed]

8. Gardner TJ, Horneffer PJ, Manolio TA, Hoff SJ, Pearson TA. Major stroke after coronary artery bypass surgery: Changing magnitude of the problem. J Vasc Surg 1986; 3:684-7. [CrossRef] [PubMed]

9. Hertzer NR, Flanagan RA, O'Hara PJ, Beven EG. Surgical versus nonoperative treatment of symptomatic carotid stenosis. Ann Surg 1986; 204:154-62. [CrossRef] [PubMed]

10. North American Symptomatic Carotid Endarterectomy Trial Collaborators. Beneficial effect of carotid endarterectomy in symptomatic patients with high-grade carotid stenosis. N Engl J Med 1991; 325:445-53. [CrossRef] [PubMed]

11. Barnett $H$, Taylor DW, Eliaszew M, Fox AJ, Ferguson GG, Haynes RB, et al. Benefit of carotid endarterectomy in patients with symptomatic moderate or severe stenosis. N Engl J Med 1998; 339:1415-25. [CrossRef] [PubMed]

12. Mayberg MR, Wilson SE, Yatsu F, Weiss DG, Messina $L$, Hershey LA, et al. Carotid endarterectomy and prevention of cerebral ischemia in symptomatic carotid stenosis. JAMA 1991; 266:3289-94. [CrossRef] [PubMed]
13. European Carotid Surgery Trialist's Collaborative Group. MRC European Carotid Surgery Trial: Interim results for symptomatic patients with severe (70$99 \%$ ) or with mild $(0-29 \%)$ carotid stenosis. Lancet 1991; 337:1235-43. [CrossRef] [PubMed]

14. Gaparis AP, Ricotta L, Cuadra SA, Char DJ, Purtill WA, Van Bemmelen PS, et al. High-risk carotid endarterectomy: Fact or fiction? J Vasc Surg 2003; 37:40-6. [CrossRef] [PubMed]

15. Reed $A B$, Graccione $P$, Belkin M, Donaldson MC, Mannick JA, Whittemore $A D$, et al. Preoperative risk factors for carotid endarterectomy: Defining the patient at high risk. J Vasc Surg 2003; 37:1191-9. [CrossRef] [PubMed]

16. Hertzer NR, Lees CD. Fatal myocardial infarction following carotid endarterectomy. Ann Surg 1981; 194: 212-8. [CrossRef] [PubMed]

17. Mackey WC, O'Donnell TF, Callow AD. Cardiac risk in patients undergoing carotid endarterectomy: Impact on perioperative and long-term mortality. J Vasc Surg 1990; 11:226-33. [CrossRef] [PubMed]

18. Trachiotis GD, Pfister AJ. Management Strategy for Simultaneous Carotid Endarterectomy and Coronary Revascularization. Ann Thorac Surg 1997; 64:1013-8. [CrossRef] [PubMed]

19. Snider F, Rossi M, Manni R, Modugno P, Glieca F, Scapigliati $A$, et al. Combined surgery for Cardiac and Carotid disease: Management and Results of a rational Approach. Eur J Vasc Surg 2000; 20:523-7. [CrossRef] [PubMed]

20. Char D, Cuadra S, Ricotta J, Bilfinger T, Giron F, McLarty $A$, et al. Combined coronary artery bypass and carotid endarterectomy: long term results. Cardiovasc Surg 2002; 10(2):111-5.

[CrossRef] [PubMed]

21. Dönmez AA, Adademir T, Sacli H, Koksal C, Alp M. Comparison of early outcomes with Tree Approaches for combined coronary revascularization and carotid endarterectomy. Braz J Cardiovasc Surg 2016; 31 (5): 365-70. [CrossRef] [PubMed]

22. Daily PO, Freeman RK, Dembitsky WP, Adamson RM, Moreno-Cabral RJ, Marcus S, et al. Cost reduction by combined carotid endarterectomy and coronary artery bypass grafting. J Thorac Cardiovasc Surg 1996; 111: 1185-92. [CrossRef] [PubMed] 


\title{
STRATEGIJA ZBRINJAVANJA BOLESNIKA SA KORONARNOM BOLEŠĆU I PRISUTNOM SIGNIFIKANTNOM STENOZOM KAROTIDNE ARTERIJE: ANALIZA "STAGED" I "CONCOMITANT" PRISTUPA
}

\author{
Saša S. Živići ${ }^{1}$ Dragan J. Milić1, ${ }^{2}$, Mile Vraneš̌ ${ }^{3}$, Miloš Velinović3 \\ Dragan C. Bogdanovićt
}

${ }^{1}$ Klinika za kardiovaskularnu sa transplantacionom hirurgijom, Klinički centar Niš, Niš, Srbija Univerzitet u Nišu, Medicinski fakultet, Niš, Srbija

${ }^{3}$ Klinički centar Srbije, Klinika za kardiohirurgiju, Beograd, Srbija

${ }^{4}$ Insitut za javno zdravlje Niš, Niš, Srbija

Kontakt: Saša Živić

Bul. Dr Zoran Đinđić 48, 18000 Niš Srbija

E-mail: zivicdr@gmail.com

I danas ne postoji nedvosmislena, jasna prepopruka o za tretman bolesnika koji se podvrgavaju revaskularizaciji miokarda, u uslovima vantelesnog krvotoka, a imaju pridruženu signifikantnu stenozu karotidne arterije. Kod ove grupe bolesnika postoji nekoliko načina u tretmanu, a našom studijom analizirali smo one koji su bili podvrgnuti "Staged" i "Concomitant" pristupu.

Tokom 2016.godine u tri kardiohirurška centra Srbije, Klinika za kardiohirurgiju KCS, IKVB Dedinje i Klinika za kardiovaskularnu sa transplantacionom hirurgijom KC Niš, analizirani su perioperativni rezultati bolesnika, podeljenih u dve grupe: podvrgnuti "faznim" i "simultanim" pristupom. Signifikantnost stenoze karotidne arterije definisana je sa $\geq 70 \%$ uz pomoć kolor dupleks skena. Grupa 1- bolesnika kojima je rađena revaskularizacija miokarda, a everziona endarterektomija karotidne arterije urađena najmanje 30 dana ranije, i Grupa 2 bolesnici kojima je istovremeno rađena everziona endarterektomija karotidne arterije sa revaskularizacijom miokarda. Nakon revaskularizacije miokarda praćena je pojava CVI verifikovanog CT-om ili MR-om u periodu od 7 dana. Praćeni su parametri koji su u ranijim kliničkim studijama isticani kao prediktori pojave intra i perioperativnog CVIa - perfuzioni pritisak na EKK, dužina trajanja okluzione kleme, vreme trajanja EKK, telesna temperatura tokom EKK, zastupljenost LM, perioperativni arterijski pritisak.

Sprovedeno ispitivanje obuhvatilo je ukupno 49 bolesnika koji su razvrstani u dve grupe. Kod 28 (Grupa 1) je everziona endarterektomija karotidne arterije urađena 30 dana do 26 meseci, a u proseku 9,61 $\pm 6,97$ meseci pre koronarne revaskularizacije. Kod 21 bolesnika (Grupa 2), je everziona endarterektomija karotidne arterije urađena je sinhrono sa revaskularizacijom miokarda. Prosečna starost bolesnika bila je 64 i 65 godina, sa predominacijom muškog pola (86\%:14\%). Jedini parametri koji su pokazivali signifikantnu razliku među grupama bili su "left main syndrome" i nestabilna angina pektoris u Grupi 2. U praćenom periodu, u obe grupe, nije bilo postoperativnih velikih neuroloških događaja (CVI). Kod jednog bolesnika javili su se klinički znaci neurološkog deficita u vidu slabosti jedne strane tela, ali CTom i MRAom nije dijagnostifikovan CVI.

Na osnovu sprovedene analize, može se zaključiti da "Staged" procedura predstavlja sigurnu i efikasnu proceduru za bolesnike koji nemaju nestabilnu anginu pektoris i koji nemaju signifikantnu stenozu glavnog stabla leve koronarne arterije. Sinhrona procedura, za bolesnike koji imaju nestabilnu anginu pektoris i imaju stenozu glavnog stabla leve koronarne arteriije, predstavlja siguran i efikasan pristup. Perfuzioni pritisak $\geq 60 \mathrm{mmHg}$, kao i umerena hipotermija tokom kardiopulmonalnog by pass-a, u sinhronoj ili "Staged" proceduri, predstavlja prevenciju neuroloških događaja.

Acta Medica Medianae 2019;58(1):44-49.

Ključne reči: revaskularizacija miokarda, stenoza karotidne arterije, "staged" procedura, "simultana" procedura 